\title{
O PROJETO ROMANIZADOR NO FINAL DO SÉCULO XIX: a expansão das instituições escolares confessionais
}

\author{
Lúcia Helena Moreira de Medeiros Oliveira \\ Universidade do Estado de Goiás - UFG/JATAÍ \\ lhmmo@bol.com.br
}

\section{RESUMO}

$\mathrm{O}$ artigo intenta apresentar reflexões a respeito do projeto romanizador no final do século XIX, e, consequentemente, a disseminação do ideário católico, por meio de suas instituições escolares. Para esse feito, foi imprescindível a análise das cartas encíclicas, escritas pelos Papas Pio IX, Leão XIII e Pio X, no período de 1860 a 1903, o que possibilitou compreender o princípio fundante e norteador da ação educacional da Igreja no período, sobretudo, apreender as intenções e finalidades da mesma, além de buscar entender as ações propostas para materialização do ideário romanizador no contexto da sociedade capitalista. Uma vez analisadas as encíclicas, infere-se que a ideia central do projeto da Igreja era ressacralizar a sociedade, converter o homem tornando-o obediente às leis da Igreja Católica por meio da educação e, desse modo, a mesma apoiou a expansão das instituições confessionais no Brasil. Nesse sentido, a instalação das Congregações Religiosas européias no Brasil convalida essa ideia e, mais que isso, suas escolas buscam formar o homem ordeiro, trabalhador e patriota.

Palavras-chave: História da Educação. História das ideias religiosas. História das instituições escolares confessionais.

\section{THE ROMANIZING PROJECT AT THE END OF XIX CENTURY: the expansion of confessional schools.}

\begin{abstract}
This paper aims at presenting reflections regarding the romanizing project at the end of the XIX century and, consequently, the dissemination of the catholic set of ideas through their schools. In order to do so, it was crucial the reading of the encyclical letters written by the Popes Pius IX, Leo XIII and Pius X, from 1860 to 1903. These letters made it possible to understand the founding principle which guides the educational action of the Church in that period, mainly to apprehend its intentions and purposes, besides understanding the actions proposed for the materialization of the romanizing set of ideas in the context of the capitalist society. After analyzing the encyclical letters, one infers that the main idea of the project of the Church was to re-sacralize society, to convert man making him obedient to the Catholic Church laws through education, and thus it supported the expansion of the confessional schools in Brazil. In this sense, the settlement of the European religious congregations in Brazil convalidates this idea. Moreover, their schools search for forming a man who is pacific, hard-working and patriot.
\end{abstract}

Keywords: History of education. History of religious ideas. History of confessional schools. 


\section{Introdução}

Este artigo é um desdobramento dos estudos a respeito da educação scalabriniana no Brasil $^{1}$ e exara algumas reflexões no entorno da história das ideias religiosas, objetivando compreender o movimento da Igreja no final do século XIX e, paralelamente, a materialização do ideário católico, por meio de suas instituições escolares. Recorreu-se, portanto, à análise das cartas encíclicas, escritas pelos Papas Pio IX, Leão XIII e Pio X, no período de 1860 a 1903, para entender o princípio fundante e norteador da ação da Igreja no período, perceber a concepção de sociedade, de história, de homem e de ciência tecida pela Igreja; sobretudo, entender as ações indicadas para consubstanciar o orbe cristão e reafirmar a ideia de mito fundante como Providencial, Divino e Criador. Nessa perspectiva, parte-se da premissa que essas ideias não são a-temporais, nem tão pouco ahistóricas, mas produtos, ações dos sujeitos nela envolvidos e, em função disso, as cartas encíclicas aqui analisadas foram, de certo modo, acordadas às necessidades que a Igreja tinha para agir em um tempo real, existente, material, sobre o mundo moderno, a ciência e o capitalismo.

Portanto, faz-se uma releitura do amplo projeto da Igreja Católica e, para essa hermenêutica, o teor das cartas encíclicas foi indispensável e, ao mesmo tempo, sua articulação ao contexto histórico e político que o produziu, possibilitou entender o tipo de sociedade a Igreja ensejou formar e, nesse sentido, compreender o papel das congregações de religiosos e de religiosas que chegaram ao Brasil no período elucidado. As cartas encíclicas analisadas nesta investigação convalidam, em suas orientações, o ideário romanizador, já que a Igreja Romana implementou um projeto e a Igreja, no Brasil, acatou-o, ratificando-o, por meio de ações que garantissem o estabelecimento do mesmo especificamente no que se refere ao acolhimento das congregações européias que aqui chegaram. Com a intenção de entender como transcorreu esse processo, buscou-se recuperar, neste texto, o projeto empreendido pela Igreja e, nesse movimento, entrever as congregações religiosas e suas instituições, dentre elas a Congregação Scalabriana.

\section{O projeto romanizador e reformador da Igreja no final século XIX}

Para tratar do projeto romanizador da Igreja, no Brasil, faz-se necessário retomar, sumariamente, alguns aspectos históricos do ideário católico desde a colônia até o início do século XX; um longo período marcado por muitas contradições ideológicas. Nesse contexto, o clero, no Brasil, dividiu-se em dois grupos, paradoxalmente antagônicos e acordados: o episcopado, defensor dos interesses lusitanos, e o clero liberal influenciado pelo ideário liberal, defensor da independência do Brasil. O clero liberal sofreu influências das ideias iluministas e racionalistas veiculadas pelas universidades de Portugal. Segundo Azzi (1992, p.33), seria essa a conformação das primeiras tentativas de dar uma coloração nacional para a Igreja no Brasil. O pensamento do clero liberal foi amplamente discutido por $\mathrm{Azzi}^{2}$; segundo o autor, o clero letrado e urbano sofreu maiores influências iluministas, exatamente, por estar em contato com a literatura, com as universidades, com o contexto no qual essas ideias ventilavam.

Desse modo, a partir dos meados do século XIX, configuraram-se, no Brasil, dois modelos distintos de Igreja. Uma Igreja já implantada, dependente da Coroa pelo regime de padroado $^{3}$, e a outra a ser implantada, também dependente, porém, orientada pelas diretrizes da Santa Sé. Em relação à primeira, o governo considerava a instituição 
eclesiástica um departamento do Estado e, em força da tradição do Padroado, permitia ao governo indicar o nome de padres e bispos; julgava, também, que lhe competia orientar a atividade apostólica (AZZI, 1992, p.33). Nesse aspecto, é fundamental ampliar algumas reflexões sobre a questão, pois o confronto entre Igreja e Estado, a disputa entre poder temporal e espiritual, poder papal e régio fundamentaram os debates teóricos europeus por longos séculos ${ }^{4}$.

Portanto, o cerne da questão continuou em aberto durante séculos e, no Brasil,

a supremacia do poder civil sobre o poder eclesiástico foi decorrente da alteração de uma prática jurisdicional comumente seguida ou de princípios geralmente aceites, sem que haja uma uniformidade na argumentação com que se pretende legitimá-lo, entende-se por regalismo. (CASTRO, 2001, p.321)

A partir desse pressuposto, pode-se referir ao regalismo no Brasil sob as influências do galicanismo ${ }^{5}$, que, desde o século XVIII, estava conectado ao ideário católico na metrópole. Em especial, no Brasil, pode-se referir ao padre Antonio Pereira de Figueiredo ${ }^{6}$ como teórico e defensor do galicanismo/regalismo, exercendo grandes influências no pensamento católico lusitano, pois, nesse período, a política pombalina objetivava banir qualquer ingerência da Igreja Romana no reino português. O principal teor de suas discussões era a defesa de Deus como autor do poder régio, porém, ao rei e ao príncipe devia sujeitar-se a Igreja, porque ambos eram considerados sagrados e invioláveis. Como escreve Chauí (2000, p.79), "um só rebanho, um só pastor. Uma só cabeça, um único cetro e um único diadema. A imagem teológica do poder político se afirma porque encontra no tempo profano sua manifestação: a monarquia absoluta por direito divino dos reis" é a justificação da sagração do governante a partir do mito fundador, Deus, criador do homem à sua imagem e semelhança. Sobre o poder divino dos reis, a autora afirma que,

pelo pecado original, o homem perdeu todos os direitos e, portanto, também o direito ao poder. Este pertence exclusivamente a Deus, pois como lemos na Bíblia: 'Todo poder vem do Alto/Por mim reinam os reis e governam os príncipes'. De acordo com essa teoria, se algum homem possuir poder é porque o terá recebido de Deus, que, por uma decisão misteriosa e compreensível, o concede a alguém, por uma graça ou favor especial. (CHAUÍ, 2000, p.82)

Aplica-se a ideia de que o rei, como ser contingente e temporal, porém, concedido por Deus, possui e deve exercer poder e que outros homens terão poder de representarem o rei. Essa ideia do Divino explica que o governante, como ser contingente e temporal, possui corpo e alma, assim como o Criador. Nesse sentido, o corpo imortal - a alma - é o corpo político, concedido ao rei no momento da coroação, quando recebe as insígnias do poder: o cetro, símbolo do poder; a coroa, o poder para dirigir; o manto, a proteção divina; a espada, o poder de guerra e de paz e o anel, símbolo do casamento do rei com o patrimônio (CHAUÍ, 2000). Articula-se, desse modo, essas premissas à concepção de regalismo que o Brasil vivenciava, pois, ideologicamente, a sagração do governante significava ser o rei representante de Deus, em primeiro lugar e, a esse corpo místico, a Igreja devia obediência.

Ainda, concernente às questões sobre a história da Igreja, ressalta-se a presença do ultramontanismo, ideário intrinsecamente relacionado à discussão arrolada nesta pesquisa. O movimento ultramontano, eminentemente europeu, emergiu no seio da Igreja francesa 
(século XVIII), condenando o ideário liberal por considerá-lo contrário aos ensinamentos sobre a organização social designada pela Providência Divina. Segundo Lustosa (1977, p.38):

\begin{abstract}
Profundamente romano, caracterizou-se pela intensificação da tendência de centralização de poder nas mãos do papa, pela uniformidade doutrinal cada vez mais acentuada e dirigida, tendo o ponto alto na definição dogmática da infabilidade pontifícia, pela convergência de esforços e pela supervalorização da moralização dos costumes, deixando em plano inferior um ensino e um conhecimento mais ligado a vida, pela "espiritualização" do clero interiormente enclausurado nas questões de Igreja e desligado dos problemas sociais e políticos. Mais ainda, o ultramontanismo combatia o liberalismo radical e juntamente rejeitava tudo quanto havia de inovação do progresso, de avanços científicos, de posições e movimentos sociais e políticos, que surgiam, naturalmente, dentro do contexto liberal.
\end{abstract}

Portanto, contrário às inovações propostas pelo mundo moderno, o ultramontanismo fortaleceu-se e expandiu-se mundialmente, a partir do Pontificado de Gregório XVI, procurando manter acesas as orientações religiosas rigorosas do Concílio de Trento (1545-1563) ${ }^{7}$ durante todo o século XIX. Nesse sentido, a partir do cômputo das cartas encíclicas, publicadas por Gregório $\mathrm{XVI}^{8}$ (1831-1844), pode-se depreender a essência do pensamento ultramontano, pois tal documento delineou um protesto às maledicências contra a Igreja, condenou a liberdade de expressão do pensamento por meio da imprensa e também a separação entre Igreja e Estado. Buscou, em seus ensinamentos, inculcar obediência à Santa Sé e às autoridades constituídas. Nesse sentido, condenou os movimentos revolucionários e qualquer violência advinda desses, relutou contra o indiferentismo e o racionalismo. Além disso, defendeu a propagação da fé por meio de instituições e incentivou as atividades missionárias. O movimento chegou ao Brasil, ainda no século XVIII, com os padres lazaristas em seus colégios e seminários - em Minas Gerais, o Colégio Caraça - marcados por formação rigorosa, disciplinar e moral cristã, no sentido de europeizar, centralizar e uniformizar os fiéis de acordo com as diretrizes ultramontanas.

Aproveitando-se das reflexões feitas por Manoel (2004, p.11) e convalidando-as, ressalta-se que o ultramontanismo, movimento de caráter reacionário, caracterizou-se no âmbito intelectual como uma rejeição à filosofia racionalista e à ciência moderna; politicamente, condenou a liberal democracia burguesa e reforçou a ideia de monarquia; externamente, também apoiou a centralidade em Roma e a figura do Papa, além de reforçar o Episcopado. No âmbito sócio-econômico, condenou o capitalismo e o comunismo, além de evidenciar um indisfarçável saudosismo à Idade Média; em relação à doutrina, "retomou" as principais decisões tridentinas - combate ao protestantismo e ao espiritismo (século XIX) - e, no Brasil, concretizou-se com a criação de seminários para formação do clero e a criação de colégios para educação da juventude - masculino e feminino. Nessa lógica, produziu uma política de rejeição à teoria do progresso, evidentemente, porque o ideário moderno, teoria poderosa, era a arma utilizada pelos seus inimigos.

Em meio a essas discussões, o conflito entre movimento romanizador e Estado brasileiro regalista, de certo modo, impulsionou a difusão do protestantismo. Abriu-se um espaço entre o Estado, que buscava a laicidade, o desenvolvimento do moderno, e a Igreja, ensimesmada, que buscava preservar o seu princípio fundante, o Sagrado. Nesse contexto, observa-se a presença das escolas e dos colégios protestantes, pois os liberais ensejavam 
outro tipo de educação, capaz de substituir o currículo das escolas tradicionais jesuíticas literário e humanista; idealizavam uma escola cuja concepção de educação fosse mais pragmática, voltada à instrução científica e técnica. Evidentemente, os missionários protestantes publicavam, nos arautos da sociedade, as ideias liberais e progressistas. Visualiza-se, portanto, no âmbito educacional, o debate entre escola protestante e escola leiga. O final do século XIX e início do outro foi contemplado com a criação de vários colégios e escolas protestantes, como se vê:

Quadro 1 - Escolas e Colégios Protestantes (1870-1914)

\begin{tabular}{|l|c|}
\hline \multicolumn{1}{|c|}{ Escolas/Colégios } & Período \\
\hline Escola Americana de São Paulo, SP & 1870 \\
\hline Colégio Internacional de Campinas, SP & 1873 \\
\hline Colégio Protestante de São Paulo, SP & 1890 \\
\hline Escola Americana de Curitiba, PR & 1891 \\
\hline Colégio Americano de Natal, RN & 1895 \\
\hline Seminário do Norte Garanhuns, PE & 1899 \\
\hline Colégio Americano de Pernambuco, PE & 1904 \\
\hline Instituto Ponte Nova -350 km de Salvador, BA & 1906 \\
\hline Colégio 15 de novembro Garanhuns, PE ${ }^{13}$ & 1908 \\
\hline Instituto Cristão de Castro & 1914 \\
\hline
\end{tabular}

Fonte: MATOS (2009).

Entende-se que a criação dessas escolas e colégios explica a ênfase dada pelos protestantes à educação e mostra o esforço em expandir-se, também, pelo Brasil, obviamente, na contramão das escolas católicas, que chegavam em grande número na América Latina, imbuídas pela política de restauração dos princípios da Igreja Católica. Segundo Hilsdorf (1986, p.186), a instalação dessas escolas tornou-se possível porque satisfaziam às tradições liberais mais caras da Província de São Paulo, porque as escolas públicas e particulares eram leigas e a Igreja provocou inflexivelmente o protestantismo e, além disso, o trabalho missionário protestante seguia uma orientação mais pragmática que teológica. As escolas ${ }^{14}$ protestantes eram chamativas, porque

o protestantitsmo era visto como uma religião ativa, enérgica, amiga da propaganda e do trabalho;[...] as escolas americanas de fé protestantes representavam a ponta de lança que abriria caminho para uma renovação das mentalidades e das práticas pedagógicas, e por extensão da sociedade brasileira, também porque concretizavam aqueles aspectos do sistema educacional (escolar) norte-americano que mais atraíam as elites da época; iniciativa privada, ensino prático, científico e comum para todos, currículo atualizado, cuidado com os aspectos materiais do ensino, aulas regulares noturnas, atividades extra-classe, suporte financeiro do capital associado. (HILSDORF, 1986, p.188)

Infere-se que o protestantismo tornou-se uma verdadeira provocação aos ensinamentos católicos e a reação católica foi de restaurar seus princípios, também, por meio de suas escolas e colégios ${ }^{15}$, além de um elenco de ações que abrangeria todos os segmentos sociais.

Portanto, a política adotada pela Igreja, em contrapartida, constituiu-se em um conjunto de atitudes teórico-práticas, cujo eixo condutor foi: a) reforço ao tradicional magistério, incluindo-se a retomada pelo tomismo; b) condenação à modernidade em todas 
as suas dimensões; c) centralização de todos os atos da Igreja em Roma, com decreto da infabilidade do Papa - Concílio Vaticano I; d) adoção do paradigma medieval para organização social, política e econômica de todos os povos. Esse projeto preservaria, de imediato, a instituição face aos perigos do moderno e, a médio e longo prazo, "recristianizaria a sociedade, recolocaria a Igreja como centro de controle do mundo", segundo Manoel (2004, p.45).

Muito instigante, interessante e contraditório é pensar a sociedade moderna, secularizada, recusando o mundo capitalista e retomando o teocentrismo,

o paradigma medieval, sucumbido pelo moderno, pela sociedade urbana, pelo mercado mundial, pela conversão do artífice em operário, em força de trabalho, em capital variável, pelo mercado mundial e pela ética do pagamento à vista. [...] Seria voltar à unidade querida por Deus e destruída pelo pecado, dissolver-se novamente no absoluto, reconstruir a Idade de Ouro perdida [...], ou seja, retomar as práticas econômicas, sociais e políticas do feudalismo, paralisar o pêndulo da história, que se afastou do centro do equilíbrio, toda estabilidade, a paz, liberdade e justiça, destruídas pelo capitalismo. (MANOEL, 2004, p.123)

Para compreender como esse ideário se estendeu ao longo dos anos, fez-se necessária uma análise mais acurada a respeito das encíclicas escritas e publicadas pelos Papas Pio IX, Leão XIII e Pio X, no período de 1860 a 1903, o que permite afirmar que, impossibilitada de reconstruir práticas do modo de produção feudal, a Igreja lança mão dos documentos pontifícios, em específico, a Rerum Novarum ${ }^{16}$, a qual sugere a restauração das corporações do ofício, associações de operários com ênfase no aperfeiçoamento moral e religioso - proposta diametralmente oposta à organização de sindicatos, movimentos gerados a partir do modo de produção capitalista. Desse modo, a Igreja, com base na doutrina de retomar o paradigma medievo, como afirma Manoel (2004, p.134), desenvolve um amplo movimento de recristianizar a sociedade pela Ação Católica, uma recristianização que negava a trajetória humana, apontava o passado como paradigma e considerava o presente, tal como era, a própria perdição humana concretizada.

Ainda referindo-se às reflexões de Manoel (2004), a partir do pontificado de Leão XIII, a Igreja se abre um pouco mais ao mundo moderno; entretanto, posiciona-se, inexoravelmente, contrária aos movimentos operários. Contraditoriamente, toda a política engendrada pela Igreja preservou a estrutura básica da sociedade moderna - propriedade privada dos meios de produção, classificando-a e defendendo-a como um direito natural.

Analisando a carta encíclica Immortale $D e i^{17}$, percebe-se como a Igreja pensava o Estado e sua relação com os homens - esses, vivendo em sociedade, necessitavam de uma autoridade para regê-los, "autoridade que, tanto como a própria sociedade, proceda da natureza e, por consequência tenha Deus por autor" (IGREJA CATÓLICA, 2005, p.239). Portanto, o Estado religioso e cristão deveria cumprir todos os ditames que o unisse a Deus, e o principal deles seria abraçar de alma e coração a religião católica e ter por santo o nome de Deus. Nesse contexto, o Estado assume a tarefa de governar as coisas humanas e a Igreja, as divinas, porém, cada um com seu próprio desempenho, distinto e soberano, trabalhando simetricamente para melhor organização da sociedade.

Entretanto, no Estado laico a orientação é contrária, pois,

cada um será livre de se fazer juízo de qualquer questão religiosa, de abraçar a religião preferir ou de não seguir nenhuma, se nenhuma lhe agradar. Daí, decorrem a liberdade de consciência, a liberdade absoluta 
de adorar ou de não adorar a Deus, a licença sem limites, não só de pensar, mas também de publicar os próprios pensamentos. (IGREJA CATÓLICA, 2005, p.250-251)

Seria esse o fito do ideário liberal que pulverizava, naquele momento, toda a Europa e, consequentemente, o Brasil. Desse modo, a questão da liberdade, natural ou moral, Leão XIII tratou em especial na carta encíclica Libertas $^{18}$. Liberdade como característica própria dos seres racionais, senhores de seus atos, de onde podem nascer os maiores males ou os maiores bens (IGREJA CATÓLICA, 2005) e que, por esse motivo, deveria ser subordinada às ordenações e às proibições da autoridade soberana - Deus -, expressa no poder na Igreja.

A ordenação e a disciplina aos ensinamentos cristãos conseguiram, ao longo dos séculos, manter a organização das sociedades, ao contrário das intenções laicistas, que ressaltavam absurda licenciosidade (IGREJA CATÓLICA, 2005), sobretudo porque derivavam do princípio do racionalismo e da supremacia da razão humana. Nesse sentido, a Igreja deveria combater as quatro principais características do liberalismo - liberdade de culto, de expressão, de ensino e de consciência. Esse conjunto de ideias instigaria as diversas insurreições que, naquele momento, as sociedades presenciavam.

Nessa reflexão, o fato de o Estado ser ou não laico torna-se um assunto intrigante, considerando que o direito de escolha religiosa, em quase todos os países, é de cada cidadão, conforme afirma Scampini (1978). Naquele contexto, relativamente ao Brasil, essa questão revelava-se mais complexa, em função de ser, desde a colonização, uma nação católica, assim consolidada durante o Império, em especial, pela Constituição de 1824, que apresenta o catolicismo como religião oficial e nacional. Acresce, nesse período, a interpretação regalista de que o poder executivo pudesse nomear os bispos e distribuí-los conforme sua vontade, mantendo sob seu julgo a organização episcopal brasileira.

Dessa forma, a facção clerical tradicionalista, nesse momento, teve como intento, reformar e conservar os princípios da Igreja, sem perder os privilégios obtidos nas relações entre Igreja-Estado, salvaguardando, ao mesmo tempo a ideia do Estado soberano, Sagrado que, em união com o clero, fortaleceria cada vez mais a nação. Nessa perspectiva, a doutrina católica deveria ser consolidada por meio da educação religiosa, objetivando "inculcar a obediência, a paciência, a disciplina e o cumprimento dos deveres cidadãos" (AZZI, 1992, p.43); e o clero, além de combater o novo e o desordeiro, inculcaria ideias que conformariam a todos, moralmente, na organização social anteriormente posta.

Observou-se, portanto, que essa facção clerical, seja na Bahia, Pernambuco, Minas Gerais ou qualquer outra parte do Brasil, desejava a união Igreja-Estado, enfatizava o poder eclesial e civil como sagrados, infalíveis e defendia o catolicismo como religião oficial do Estado. A tríade, poder civil, eclesial e a educação religiosa, seria o sustentáculo da reforma, do combate ao laicismo e ao liberalismo no Brasil.

Para aprofundar especificamente nessa discussão, lançou-se mão dos pressupostos apontados pela Igreja no documento Sillabus ${ }^{19}$ no qual foram apresentadas oitenta proposições sobre as condenações que Pio IX havia feito ao mundo moderno por meio de seus escritos. Desse modo, ressaltaram-se os erros referentes às concepções liberais modernas e, especialmente, a não oficialidade da religião católica pelo Estado. Segundo a Igreja, essa questão constituía-se um equívoco, pois ao homem não caberia individualmente praticar um culto próprio, indiferente ao catolicismo. A liberdade de culto poderia corromper as mentes e propagar as ideias corruptas da modernidade, do progresso, da ciência e do liberalismo. 
Essas mesmas ideias também foram combatidas na carta encíclica Quanta Cura $^{20}$ e, posteriormente, essas proposições foram anexadas ao Sillabus, enfatizando, sobretudo, os objetivos enganosos do comunismo e do socialismo ao afastar a doutrina da Igreja Católica da instrução e da educação da juventude. Grave erro, afirmava Pio IX, pois à família cabia escolher sobre a educação de seus filhos (IGREJA CATÓLICA, 1999).

Observou-se, também, na encíclica, a retomada da questão da unidade da Igreja de Cristo, a Igreja Romana e o desejo em recuperar o que ainda era possível, prioritariamente, em relação à exclusão da Igreja quando o Estado prescindiu o ensino religioso dos currículos e da administração pública, suprimiu as ordens religiosas e qualquer outra ligação entre Igreja e Estado. De todo modo, o documento enfatizou a importância da unidade entre ambos, nomeando-a como o fio condutor do movimento ultramontano.

Retomando questão específica, no Brasil, das divergências entre ultramontanos e tradicionalistas ou regalistas, outro aspecto há de se ressaltar sobre o pensamento católico tridentino - estabelecido desde o Concílio de Trento e reafirmado ao longo dos próximos quatro séculos - traduzido basicamente na ideia de que à Igreja autônoma caberia a preparação espiritual da humanidade e ao Estado soberano, cuidar das questões políticosociais e econômicas, de forma que não houvesse ingerência de nenhum dos lados, ou seja, cada um responderia pelos seus distintos papéis. Essa relação não pressupunha uma ruptura, segundo Azzi, nenhuma infidelidade ao Império; pelo contrário, os bispos levantariam a bandeira de um governo autoritário e centralizador, já que Igreja e Estado deveriam comungar as mesmas ideias.

Contudo, pode-se afirmar que, em alguns aspectos, os dois modelos de Igreja, que ora coabitavam o país, eram convergentes, sobretudo no que se referia à educação religiosa católica, instrumento indispensável para manutenção da ordem social. Entende-se, nessa perspectiva, a consolidação da reforma, a recuperação da autonomia eclesial e a conservação do Estado Sagrado, derivado da Providência Divina, o qual deveria ser respeitado inquestionavelmente. Eis, portanto, a tarefa da Igreja - formar uma sociedade cristã. Esse foi o ponto chave da união Igreja-Estado, o orbe cristão. O fragmento abaixo amplia essa discussão:

A relação entre a religião e a sociedade remete para um outro aspecto vinculado a este: a Igreja como permeadora de todos os processos sociais. Tudo deve se organizar com base em princípios cristãos. Essa é a bandeira do episcopado em 1890: a sociedade brasileira, inclusive o grupo politicamente dirigente, deve respeitar, amar e não se separar da Religião. (ARAÚJO, 1986, p.63)

Discutindo, ainda, a relação Estado-Igreja é preciso ressaltar a Questão Religiosa. No caso específico do Brasil, como se sabe, desde o período colonial, a Igreja submetia-se ao Estado pelo regime de padroado e todas as ordens do Papa passavam pelo crivo do imperador. Por volta de 1872, os bispos de Pernambuco e Pará, Olinda e Belém, respectivamente, decidiram punir certas irmandades religiosas que apoiavam a maçonaria, baseados nas orientações do papa Pio IX na Carta Encíclica Exorte in ista ${ }^{21}$, endereçada aos bispos do Brasil:

[...] Afinal, não podíamos permanecer indiferentes ao fato de que a peste letal daquela seita se havia difundido até conseguir corromper as mencionadas comunidades, e, conseqüentemente, as instituições dispostas a reforçar o espírito sincero da fé e da piedade, depois que havia sido espalhada a funesta cizânia, precipitaram numa mísera condição. [...] 
Encarregamos-te, venerável irmão de Olinda, para suprimir e declarar suprimidas as mencionadas comunidades se, transcorrido aquele período de tempo, não se tivessem revisto e para reconstituí-las integralmente com as modalidades que tinham na origem, inserindo novos membros imunes de toda contaminação com a maçonaria. Nós, por outro lado, desejando pôr em alerta - como é nosso dever - todos os fiéis contra as astúcias e as insídias dos membros das seitas, na carta encíclica de 21 de novembro de 1873, endereçada aos bispos de toda a catolicidade, convocamos com clareza naquela ocasião à memória dos fiéis as disposições pontifícias emanadas contra as sociedades corruptas dos que aderem às seitas e proclamamos que nas constituições eram atingidas não só as associações, maçônicas constituídas na Europa, mas também todas as que estão na América e nas outras regiões do mundo. (IGREJA CATÓLICA, 1999, p.328-329)

Por esse motivo, os bispos foram punidos e condenados a quatro anos de prisão. A atitude da Santa Sé foi de reconciliar e, de certa forma, manter as relações estáveis com o poder monárquico brasileiro, evitando, assim, o agravamento da situação com a expulsão dos bispos do país, ou a ruptura política entre Estado e Igreja. Segundo Azzi (1992), de um lado, a Igreja desejava independência, autonomia para desenvolver, a seu modo, o poder espiritual e, por outro, objetivava consolidar-se dentro do aparelho político do Estado. A busca da primazia do poder espiritual exigia outras diretrizes, pautava-se em valores, anteriormente, veiculados pelo Concílio de Trento, em detrimento da Reforma Protestante; sem dúvida, outra abordagem eclesial. Fazia-se necessário, então, reformar o clero, reformar o povo e seus costumes, re-educá-los de acordo com uma nova eclesiologia. Desse modo, foram implementadas as visitas pastorais, as missões para o povo - tarefas confiadas aos religiosos e religiosas vindos da Europa para o Brasil.

As religiosas e os religiosos tinham a incumbência de instruir o povo por meio do evangelho e, a partir disso, regulamentar a vida sacramental - batizados, confissões, casamentos, crismas e outros. O clero, por sua vez, foi reformado, também, conforme esse modelo, com reforço ao celibato e à santidade, uma roupagem, acima de tudo, espiritual. Hierarquicamente, buscou exercer o controle sobre todas as atividades religiosas do país. Observou-se, também, nesse mesmo movimento, a participação efetiva das mulheres, em especial em associações e grupos, com fins de trabalhar para manutenção da ordem social vigente, em detrimento das novas concepções ideológicas que invadiam a sociedade brasileira.

Nessa perspectiva, chama atenção o embate entre ensino religioso e ensino leigo, presente nessas discussões, a partir de meados do século XIX. Os liberais defendiam o ensino laico em detrimento ao ensino confessional, disseminado pelos institutos e colégios religiosos à base dos ensinamentos tridentinos, os quais eram considerados, pelo clero, como instrumentos da manutenção da sociedade ordeira, conservadora e pura.

Nesse sentido, é possível entrever-se a Congregação Scalabriniana, objeto de profundos estudos, imbuída em tais orientações e diretrizes, buscando fundar escolas e colégios em várias cidades brasileiras, educar segundo os princípios tridentinos e, além disso, enfatizar as vocações. Evidencia-se, no período estudado, a presença de outras congregações femininas, também com atuação mais efetiva em colégios e hospitais, inseridas no contexto reformador da Igreja. Essa ação reformadora, em seu sentido mais abrangente, atingiria o bispo, o templo, a missa, os sacramentos, os fiéis e objetivava dar à Igreja do Brasil o matiz da Igreja romana, iniciando-se, assim, o processo de romanização. Além das instituições religiosas já instaladas no país, observou-se, nesse contexto, a 
chegada de outras frentes religiosas, masculinas e femininas, cujos objetivos eram ampliar o projeto romanizador, como já se referiu anteriormente, sobretudo segundo diretrizes do Papa Leão XIII.

\subsection{O projeto da Igreja e a expansão das congregações}

Do breve histórico acima apresentado em relação às concepções ideológicas da Igreja, justapostas por sinal, pode-se afirmar que a concepção ultramontana consolida-se, no Brasil, no final do século XIX, principalmente em função do comportamento de alguns bispos que buscavam orientações do Pontificado e não da Coroa. Além disso, nota-se a presença de núncios, internúncios, seminários voltados para formação do clero ultramontano, escolas e colégios dedicando-se à educação de jovens e de crianças, segundo os princípios dessa mesma Igreja. Contudo, a Igreja, firme em seu propósito, anunciava a sujeição do poder monárquico ao Pontificado Romano e, nesse sentido, o Papa, representante oficial desse poder, passa a ser a autoridade máxima, com a primordial tarefa de direcionar e orientar eticamente a vida em sociedade. Nesse contexto, as encíclicas cumprem esse papel, pois são inúmeros os assuntos tratados e as orientações nelas contidas explicitam o objetivo de disciplinar a todos, conforme os ensinamentos do Pontificado romano.

Entende-se, portanto, que, no Brasil, o clero liberal e o ultramontano, apesar de algumas convergências, ensejavam interesses notadamente antagônicos. Os primeiros lutavam para dar à Igreja o matiz do catolicismo nacional, e os últimos, "acentuar" o caráter universalista da Igreja Romana (AZZI, 1992, p.71). Nessa ambiência, também se contrapunham as ideias perniciosas de liberdade e de progresso, a busca pela participação na política e a notável insatisfação com o quadro político vivenciado pelo país. Nesse sentido, vale ressaltar que

\footnotetext{
A Igreja, entretanto, via este período de transição como um todo: atrás de cada pretensão liberal ou mudança, por menor que fosse, estava o perigo de uma ruptura ou de uma destruição dos quadros de valores tradicionais. O mais simples era fechar-se completamente ao diálogo e à participação. E quanto mais fervia o caldo da cultura, mais a Igreja denunciava nele bacilos de toda espécie e procurava a imunização, trancando-se na redoma de um antiliberalismo ferrenho ou de um ultramontanismo coerente. (LUSTOSA, 1977, p.41)
}

Desse modo, a Igreja, retraída, fechou-se em si mesma, afastando-se das questões políticas e sociais, enfatizando, assim, o aspecto de maior relevância do projeto ultramontano: o espiritualista.

Com a Proclamação da República, consolidou-se a supremacia política dos senhores do café e, ao mesmo tempo, chegaram grandes levas de imigrantes para substituir o trabalho escravo nas lavouras. Nesse mesmo contexto, chegaram, também, as congregações religiosas, em específico a Congregação de São Carlos Borromeo Scalabriniana, coordenada por Scalabrini, cujos objetivos e projetos eram disseminar a doutrina cristã e a cultura italiana por toda a América onde houvesse núcleos italianos. Com esse fito, a Congregação Scalabriniana chegou ao Brasil, trazendo missionários e missionárias, envolvendo-se com a educação, fundando colégios, noviciados, asilos e hospitais. 
Nota-se, que não só scalabrinianos e scalabrinianas chegaram ao Brasil nesse período. Moura (2000), em sua vasta obra sobre a vida religiosa no Brasil, compilou alguns dados importantes sobre a questão, conforme Quadro 2. É fundamental ressaltar que os dados apresentados por ele também foram entrecruzados com informações dos relatórios do Centro de Estatísticas Religiosas e Investigações Sociais - CERIS.

Quadro 2 - Colégios/Escolas/Institutos - Congregações Femininas (1890-1920)

\begin{tabular}{|c|c|c|c|}
\hline Ano & Instituição & Congregação & Localidade \\
\hline 1892 & Colégio N.S. Carmo & Filhas de $\mathrm{M}^{\mathrm{a}}$ Aux. Salesianas & Guaratinguetá-SP \\
\hline 1895 & Escola Noturna Gratuita & Filhas de $\mathrm{M}^{\mathrm{a}}$ Aux. Salesianas & Araras-SP \\
\hline 1895 & Colégio N.S.Auxiliadora & Filhas de $\mathrm{M}^{\mathrm{a}}$ Aux. Salesianas & Araras-SP \\
\hline 1896 & Colégio N.S. Auxiliadora & Filhas de $\mathrm{M}^{\mathrm{a}}$ Aux. Salesianas & Ponte Nova-MG \\
\hline 1903 & Academia St ${ }^{\mathrm{a}}$ Gertrudes & Beneditinas & Olinda-PE \\
\hline 1904 & Colégio N.S.Auxiliadora & Filhas de $\mathrm{M}^{\mathrm{a}}$ Aux. Salesianas & Batatais-SP \\
\hline 1906 & Colégio $\mathrm{St}^{\mathrm{a}}$ Escolástica & Beneditinas & Sorocaba-SP \\
\hline 1907 & $\begin{array}{c}\text { Colégio das Cônegas de } \mathrm{St}^{\circ} \\
\text { Agostinho }\end{array}$ & $\begin{array}{c}\text { Congregação N.S. Cônegas de } \mathrm{St}^{\circ} \\
\text { Agost. }\end{array}$ & São Paulo-SP \\
\hline 1907 & Anexo Colégio N.S.Aux. & Filhas de $\mathrm{M}^{\mathrm{a}}$ Aux. Salesianas & Ponte Nova-MG \\
\hline 1907 & Colégio S. Inês & Filhas de $\mathrm{M}^{\mathrm{a}}$ Aux. Salesianas & São Paulo-SP \\
\hline 1912 & Não há registro/nome & Irmãs Marcelinas & Botucatu-SP \\
\hline 1912 & Colégio Assunção & Irmãs Assunção & Rio de Janeiro-RJ \\
\hline 1914 & Escravas do DivinoCoração & Escola São Marcelo & Campo Comprido-RJ \\
\hline 1915 & $\begin{array}{c}\text { Irmãs S. Carlos Borromeo } \\
\text { Scalabrinianas }\end{array}$ & Colégio N.S.Medianeira & Bento Gonçalves-RS \\
\hline 1917 & Colégio N.S.Auxiliadora & Filhas de $\mathrm{M}^{\mathrm{a}}$ Aux. Salesianas & Araguaiana-MT \\
\hline 1918 & Filhas de $\mathrm{M}^{\mathrm{a}}$ Aux. Salesianas & Colégio Imaculada Conceição & Corumbá-MT \\
\hline 1918 & Filhas de $\mathrm{M}^{\mathrm{a}}$ Aux. Salesianas & Externato N.S.Auxiliadora & Belenzinho_SP \\
\hline 1919 & Beneditinas & Colégio N.S.Carmo & Recife-PE \\
\hline 1920 & Beneditinas & Colégio Sagrado Coração & Caruaru-PE \\
\hline 1920 & Beneditinas & Centro Social São José & Caruaru-PE \\
\hline 1920 & Beneditinas & Instituto Imaculada Conceição & Itapetininga-SP \\
\hline
\end{tabular}

Fonte: MOURA (2000).

Depreende-se do quadro acima que as Congregações femininas, paulatinamente, se instalaram, principalmente, no estado de São Paulo e ampliaram suas atividades na área educacional nos anos vinte, momento em que a Igreja reestruturou todo projeto de restauração da catolicidade brasileira. Entende-se, também que, em função do seu próprio sustento financeiro, essas Congregações educaram, nesse período, filhos de classe média, pequenos e médios proprietários rurais. Essa educação confessional pautou-se em princípios do movimento restaurador objetivado pela Igreja e, sobretudo, agiu em conformidade com os padrões culturais europeus; reconhece-se essa atitude como europeização.Como já se acentuou, o grande responsável pela instalação dessas instituições no Brasil é o movimento maior, a romanização, ou ultramontanismo. De caráter antiliberal, ensejava, consubstancialmente, preservar os dogmas católicos em detrimento das modernas ideologias.

Em consonância com esse ideário, a Congregação Scalabriniana procurou atuar nos núcleos coloniais italianos, buscando recuperar a doutrina católica apostólica romana e, concomitantemente, reafirmar a nacionalidade. De modo geral, as atividades educativas possibilitavam o binômio educação-religião. Interessante relembrar que a Constituição de 1891 havia rompido com o ensino de educação religiosa no âmbito público e, nesse sentido, as escolas laicas e protestantes figuravam nesse contexto como antídoto do 
catolicismo. Esse foi o principal motivo que levou o clero brasileiro a ampliar sua rede de escolas e de colégios com perfil bem distintos dos outros, enfatizando o currículo de cunho mais literário, clássico e propedêutico (AZZI, 1992) - estilo bem aceito e procurado pela parte mais tradicional da sociedade brasileira, bem como pela burguesia nascente, classe bem atendida nos colégios evidenciados e, como se afirmou, nos colégios da Congregação das Irmãs de São Carlos Borromeo Scalabrinianas.

Vê-se, pois, que no âmbito educacional, nada é muito novo, visto que os colégios confessionais enquadraram-se em um determinado modelo. Configurou-se, portanto, dois modelos distintos - de um lado, os colégios confessionais, para atender boa parte da classe favorecida da sociedade brasileira e, do outro, a escola profissionalizante e de caráter assistencial, para atender à classe menos abastada. Essa característica, de escola profissionalizante, apareceu na carta encíclica Fin Dalla Prima ${ }^{22}$, quando Pio XI referiu-se à fundação de patronatos para acolhimento de crianças abandonadas, sobretudo, às corporações de artes e ofícios, assunto já abordado por Leão XIII na carta encíclica Rerum Novarum.

Ainda discutindo a questão dos institutos educacionais, segundo Azzi (1994), no final do século XIX, o pensamento católico europeu, marcado pelo ultramontanismo, usou como instrumentos os institutos religiosos que tiveram a função de transplantar para o Brasil o seu ideário.

Prosseguindo à análise do pensamento da Igreja no Brasil, arrolaram-se no contexto republicano, além da visão conservadora, outras concepções ideológicas significativas e que influenciaram as tomadas de decisões da Igreja. O positivismo apresentou-se como ideia propulsora do progresso e da ordem; o liberalismo pautou-se na liberdade e no progresso e, ainda, afloraram as ideias socialistas. Essas ideologias foram amplamente debatidas e disseminadas; influenciaram não só as decisões da Igreja em relação aos institutos educacionais, mas também a sociedade.

Também foi nos primórdios da República que a Igreja sentiu-se rejeitada pela estrututura governamental, a partir da promulgação do decreto de separação Igreja e Estado, implicando, em primeira mão, na laicização do ensino e dos cemitérios e na obrigatoriedade do casamento civil. Sobre essa questão, ressalta-se a carta pastoral coletiva de 1890, que explicitou o pensamento dos bispos brasileiros, cujo teor referia-se à vontade de que a "sociedade brazileira toda inteira, compreendida sua parte dirigente, respeite a Religião, ame a Religião, não se separe da Religião, antes ame seus atos públicos ou privados, se inspire nos dictames sagrados que ella impõe à consciência" (CARTA PASTORAL, 1890, p.4). Do ponto de vista dos prelados, o caráter leigo da República, imposto à nação, desconsiderava, sobretudo, a legitimidade do povo brasileiro católico cristão. Essa atitude ou medida não comungava dos ideais da maioria da nação, e sim de um grupo minoritário e ateu. Muito significativa a afirmação da carta pastoral de 1890:

Que será de ti, coitado e querido povo do Brazil se além de tudo te roubam também a tua fé, e ficas sem Deus, sem Deus na família, sem Deus na escola, sem Deus no governo e nas representações públicas, sem Deus nos últimos momentos da vida, e até Ana morte e na sepultura sem Deus! Será possível! (CARTA PASTORAL, 1890, p.7)

Desse modo, os bispos assumiram a seguinte posição, em nome, pois, da ordem social, "em nome da paz publica, em nome da concórdia dos cidadãos, em nome dos direitos da consciência, repellimos os catholicos a separação da Egreja e do Estado; exigimos a união entre os dois poderes" (CARTA PASTORAL, 1890, p.7). 
A Constituição de 1891 dispôs sobre a liberdade individual e também sobre a liberdade de todos os credos de expressar publicamente seu culto, reconheceu somente o casamento civil, determinou que os cemitérios fossem administrados pela autoridade municipal e que o ensino ministrado nas escolas oficiais fosse leigo. Além disso, nenhum culto ou igreja seria subvencionado ou aliado à União ou ao Estado e todos os cidadãos, independentes do credo ou da função religiosa, teriam resguardados seus direitos. $\mathrm{O}$ protesto a essa ruptura, combate a essas medidas, foi veiculado nas primeiras décadas da República em todas as pastorais, jornais e periódicos católicos. Tal protesto foi uma conclamação, expressando que o sustentáculo da nação não poderia deixar de ser a religião, como tradicionalmente o era desde a colonização. Em relação ao laicismo, a Carta Pastoral (1890, p.10) esclareceu que

todo esse laicismo levaria a desorganização social, um tremendo dilúvio de erros, cada qual mais pernicioso, que alaga a sociedade moderna, máxime na Europa e nas duas Américas, ameaça arrastar e subverter tudo em suas águas lodosas e pestilentas, tudo: família, instituições, leis, religião, sociedade!

Vê-se, portanto, diante do estado leigo, esforço significativo por parte do episcopado para combater as ideias liberais e socialistas e, consequentemente, a proliferação do protestantismo e do espiritismo, em função da liberdade de culto. Esse combate, considerado por Azzi (1994), apologético e de certa forma exagerado, ou até mesmo desconectado da realidade brasileira, alastrou-se e a Igreja manteve-se fortalecida, expandindo-se na área educacional e social, praticamente em toda primeira República, conforme mostra o quadro a seguir:

Quadro 3 - Congregações Religiosas (1890-1920)

\begin{tabular}{|c|c|c|}
\hline Ano & Congregação & N. $^{\mathbf{0}}$ Colégios \\
\hline $1890 / 1918$ & Jesuítas & 09 \\
\hline $1903 / 1920$ & Beneditinos & 17 \\
\hline $1890 / 1919$ & Salesianos & 38 \\
\hline $1892 / 1920$ & Franciscanos & 05 \\
\hline $1908 / 1923$ & Carmelitas & 06 \\
\hline $1890 / 1918$ & Maristas Peq. Irmãos Maria & 49 \\
\hline $1820 / 1915$ & Lazaristas & 04 \\
\hline
\end{tabular}

Fonte: MOURA (2000).

Os salesianos instalaram seus colégios, a partir do final do século XIX, em vários estados brasileiros, atuando desde a educação infantil, fundamental e profissionalizante, até o significativo trabalho vocacional e a educação com os índios bororos. Já os franciscanos tiveram participação maior em estados do sul e sudeste, trabalhando com educação infantil, escola de música e canto. Os lazaristas chegaram ao Brasil e, durante o Império, seu grande marco foi o Colégio Caraça, em Minas Gerais, dirigido pelos padres da Congregação da Missão; além do Colégio (1820-1912), fundaram o Seminário Maior de Mariana (18561882) e uma Escola Apostólica (1885-1895 e 1905-1968) para a formação do clero lazarista e, ainda, o Colégio de Campina Verde, MG. O funcionamento do Colégio Caraça foi interrompido entre 1842-1856, retomando suas atividades entre 1856/1912, ano que entrou em declínio. Conforme o quadro acima, a obra educacional marista ampliou-se, 
significativamente, por várias partes do Brasil, atendendo à educação infantil, fundamental, média, profissionalizante e vocacional; após os anos 30, segundo Moura, continuou a expandir-se.

A ação combatente às novas correntes filosóficas ou religiosas fez-se à luz dos princípios da Igreja na qual os principais elementos eram a ordem, a disciplina e a obediência ao poder da Igreja e do Estado e esse, ainda que leigo, era revestido pelo Divino e pelo Sagrado. Nesse processo, infere-se que a atitude conservadora dos prelados quanto à sacralidade do poder republicano e à insistência na união Estado e Igreja fez-se em função da preservação e da manutenção da ordem da sociedade brasileira (AZZI, 1994, p.45), além de declarar a ilegitimidade da ética republicana.

Outro aspecto a assinalar, referente ao período, inclusive expresso na carta encíclica Rerum Novarum (2005), era o empenho da Igreja em acomodar o "pobre" na sua condição de operário ou trabalhador como predestinação da Providência Divina e não como consequência própria do sistema sócio-econômico do país. Desse modo, aquietariam-se os ânimos, evitando-se a adesão maciça ao anarquismo e ao socialismo; aos movimentos grevistas, verdadeiros atentados à ordem, evitariam o surgimento e o desenvolvimento da consciência de classe. Observa-se o desejo da Igreja, um pouco assustada e ofendida pelos movimentos socialistas, de alertar sobre os direitos e os deveres dos operários, do patrão e do estado. Quanto aos deveres, o proletariado deveria ser comprometido com o trabalho e o Estado, mediador e conciliador entre patrão e operário. Tratava-se de estabelecer regras para disciplinar a sociedade moderna, como afirma Manoel (1992, p.23),

a proposta normatizadora aponta seus próprios limites e cerceamentos. Trata-se de normatizar, isto é, de estabelecer normas para o funcionamento e de normalizar, de fazer voltar à normalidade, à ordem. $\mathrm{O}$ limite: a sociedade deve funcionar conforme normas estabelecidas. $\mathrm{O}$ cerceamento, essas normas devem ser perenes e imutáveis.

Tais normatizações levariam o proletariado, na lógica do sistema capitalista, a ceder a qualquer opressão e exploração, contribuindo para a harmonia social. Nesse sentido, o cômputo das cartas encíclicas escritas por Leão XIII, de 1878 a 1903, dirigidas a todos os patriarcas, primazes, arcebispos e bispos do mundo inteiro, tendiam a condenar o socialismo, o comunismo e o niilismo, estabelecendo certas regras para o possível combate. Anunciava-se entre elas a Quod Apostolici Muneris ${ }^{23}$, na qual se afirmava serem os três movimentos acima, ideologicamente, opositores à autoridade, ao matrimônio, à família e à propriedade privada (IGREJA CATÓLICA, 2005, p.37), portanto, contrários à idéia do Divino, do Sagrado naturalmente. Segundo a carta, sendo a propriedade um direito natural, não deveria ser distribuída comumente como instigavam as indutoras doutrinas venenosas:

[...] tanto o ódio da plebe sediciosa contra a veneranda majestade e o império dos reis e nesse sentido, os plebeus, cansados de suas pobres casas e das oficinas, desejem ardentemente lançar-se sobre os palácios e as fortunas dos mais ricos, não há de se admirar que sacudidas, vacilem toda autoridade pública e toda tranqüilidade privada e que a humanidade tenha quase chegado à sua ruína extrema. (IGREJA CATÓLICA, 2005, p.39)

Em particular, o socialismo, do ponto vista da Igreja, disseminava a ideia de igualdade natural e, nesse sentido, ninguém devia obedecer a ninguém, exceto as leis 
construídas coletivamente. Ainda, em relação ao direito à propriedade privada, o socialismo a considerava uma invenção humana, concepção antagônica à ideia fundadora e criadora de Deus. Desse modo, a Igreja, sábia e soberana, reconhecia as desigualdades em relação aos bens materiais entre as classes sociais, entretanto, justificava-as pelas adversidades físicas e pelas capacidades de trabalho (IGREJA CATÓLICA, 2005).

Interessante, também, anunciar que esse mesmo movimento reformador sugeria a renovação da filosofia nas escolas, nos colégios e nos seminários, com ênfase na obra de Tomás de Aquino, logo no final do século XIX. Esse assunto foi pauta da carta encíclica Aeterni Patris ${ }^{24}$, Leão XIII:

Sabe-se que quase todos os fundadores e legisladores das Ordens religiosas mandaram aos seus seguidores estudar as doutrinas de Santo Tomás e de segui-las com a máxima fidelidade, precavendo-os a que para nenhum deles era lícito afastar-se impunemente, ainda que pouco, das pegadas de tão grande doutor. (IGREJA CATOLICA, 2005, p.87)

Delineou-se, portanto, um esforço em todos os sentidos em redimensionar os ensinamentos católicos a partir da literatura tomista, pois o douto angélico "explorou as conclusões filosóficas nas razões íntimas das coisas e nos princípios universalíssimos, as quais em seu seio encerram as sementes de verdades quase infinitas que, em tempo oportuno e com fruto abundantíssimo, seriam feitas germinar pelos futuros mestres (IGREJA CATÓLICA, 2005, p.86).

Revelou-se, assim, um esforço para restaurar a filosofia cristã em todas as escolas, como introdução fundamental à teologia, que já havia sido plantada e, agora, avivada pelo matiz da filosofia de Tomaz de Aquino. A Carta Pastoral (1890, p. 67) também referiu-se à desordem intelectual pela qual passava a sociedade brasileira:

Não vemos nas escolas, desde as infimias até as superiores, erguerem-se cathedras de pertilencia a exhalar os seus miasmas deletérios, e enquanto n'esses santuários polluidos da sciencia, os professores do atheismo pervertem a incauta mocidade sedenta de saber, não vemos outros emissários do mal, não menos criminoso, apoderarem-se da imprensa e por meio d'ella corromperem o povo e desnortearem o espírito público?

O expresso nesse documento significava rejeitar oficialmente todas as outras tendências filosóficas e teológicas existentes, ainda que não materialistas ou ateias (MANOEL, 2004, p.11). Diante de situação tão preocupante, os bispos indagavam sobre o que fazer e a carta pastoral de 1890 alertava que "É hora de surgir do somno, de despertar da inércia, de estimular brios, de agir com valor e de concerto, de combinar um grande e generoso esforço para defender, restaurar e fazer florescer a nossa Religião e salvar a nossa pátria” (CARTA PASTORAL, 1890, p.68).

É possível entrecruzar essas informações com a pastoral coletiva de $1900^{25}$, na qual os bispos brasileiros consideravam o novo século, indiferente, descrente e infiel:

Com efeito, todos os germes de destruição, que incubavam no seio do Império, se desenvolveram instantaneamente e produziram frutos de morte na formação da República. Proclamar tal liberdade de cultos, nivelando a Igreja Catholica, única, divina, com as superstições inventadas pelos homens, que só servem para arrastar as almas à perdição eterna. Proclamar tal liberdade de cultos é declarar que Jesus Cristo tanto 
como Mafoma e o Catolicismo tanto como o Budismo e os inventos do Confúcio. (CARTA PASTORAL, 1900, p.63)

Nessa perspectiva, os bispos proclamaram:

Se deveras amamos nossa pátria, se a queremos ver próspera, respeitada, tranqüila e una, trabalhemos a todo nosso poder para restituir a Jesus Cristo. Procuremos que Jesus seja reconhecido e adorado pela sociedade e não só pelos indivíduos; pública e oficialmente, e não só no interior das casas, no recinto dos templos e junto aos altares. Esforcemo-nos por cancelar do nosso código fundamental essas leis de apostasia que são a desgraça da nação brasileira (CARTA PASTORAL, 1900, p.65).

E fizeram ainda uma recomendação especial aos sacerdotes, referindo-se ao vigor da fé e do patriotismo, ao trabalho da Igreja, "promovendo obras de piedade, que plantem e nutram a fé no coração dos brasileiros, corrijam os erros da vida, santifiquem seus preceitos, recebam seus sacramentos e, dêsde os tenros anos fujam do pecado como peste infernal e se tome de amor pela virtude" (CARTA PASTORAL, 1900). Ainda, os bispos expressavam seus objetivos:

Queremos unir em um fascículo os interesses do indivíduo, da pátria, de Deus, ficando o homem feliz, a pátria próspera e respeitada. Deus conhecido, amado e obedecido. Esta tríplice glorificação do homem, da pátria, de Deus, é o alvo aonde atiram os nossos ardentíssimos anelos como brasileiros, como cristãos, como bispos. (CARTA PASTORAL, 1900, p. 68)

Nesse sentido, observou-se significativa preocupação dos mesmos com a educação:

Decretou-se que nossas escolas primárias e superiores fossem seminários de ateísmo, onde nada se ensinasse de religião, nada de Deus. Este nome adorável poderão os mestres proferir para o insultar ou negar, não terão liberdade de infundir na inteligência e no coração dos alunos conhecimentos e amor de Deus Criador deles e do Universo, e de Jesus seu Unigênito Filho, nosso Redentor. (CARTA PASTORAL, 1900, p. 64)

Em meio a essas discussões, é possível inferir, mais uma vez, a eminente preocupação e interesse da Igreja pela vinda das Congregações religiosas européias para o Brasil e a consequente incumbência de disseminar o catolicismo romanizado por meio de suas instituições. A educação seria o meio, a romanização a finalidade e os princípios seriam os conhecimentos de Deus Criador e Onipotente. Nessa mesma diacronia, o projeto que se instalava ao final do século XIX e que seria o sustentáculo da nova era, tinha seu ideário fundado na Igreja, objetivando formar o homem republicano e católico.

\section{REFERÊNCIAS}

ARAÚJO, José Carlos. Igreja Católica no Brasil. São Paulo: Paulinas, 1986. AZZI, Riolando. A crise da cristandade e o projeto liberal. História do Pensamento Católico. v. 2. São Paulo, Paulinas, 1991. 
O Estado leigo e o projeto ultramontano. História do pensamento Católico.v. 4. São Paulo, Paulus, 1994.

- A Neocristandade - um projeto restaurador. História do Pensamento Católico.

v. 5. São Paulo, Paulus, 1994a.

CARTA PASTORAL. Episcopado Brasileiro aos fiéis da igreja do Brasil. São Paulo:

Typografia a vapor de Jorge Seckeler \& Cia, 1890.

CHAUÍ, Marilena. Brasil - mito fundador e sociedade autoritária. Rio de Janeiro:

Fundação Persa Abramo, 2000.

FRANCESCONI, Pe. Mario. Inizi Della Congregazione Scalabriniana (1886-1888).

Roma: Centro Studi Emigrazione, 1969.

. Storia della Congregazione Scalabriniana: Lê peime missioni nel Brasile

(1888-1905), Roma: Centro Studi Emigrazione, 1973. v. 3.

HILSDORF, Maria Lúcia Spedo. Francisco Rangel Pestana: jornalista, político e educador. 1986. Tese (Doutoramento em Educação) - Progra ma de Pós Graduação em Educação, Universidade de São Paulo, São Paulo, 1986.

IGREJA CATÓLICA. Papa (1831-1878: Gregório XVI e Pio IX) in Documentos da Igreja. São Paulo: Paulus, 1999.

. Papa (1878-1903: Leão XIII) in Documentos da Igreja. São Paulo: Paulus, 2005.

LUSTOSA, Oscar F. Reformistas na Igreja do Brasil - Império, São Paulo, Boletim no 17, 1977.

MANOEL, Ivan Aparecido. O pêndulo da história: um tempo e eternidade no pensamento católico (1800-1960). Maringá: Eduem, 2004.

MOURA, Pe. Laércio Dias de. A educação católica no Brasil. São Paulo: Loyola, 2000.

PASTORAL COLETIVA. Pastoral coletiva do episcopado brasileiro. São Paulo: Escola

Tipográfica Salesiana, 1900.

PAULO II, João. Código de Direito Canônico. São Paulo: Loyola, 1987.

QUIDORT, João. Sobre o poder régio e papal. Tradução de Luís A. de Boni. Petrópolis: Vozes, 1989.

SCALABRINI, João Batista. A emigração italiana na América. Tradução de Redovino Rizzardo. Caxias: Centro de Estudos de pastoral migratória, Universidade de Caxias, 1979.

SCAMPINI, Pe. José. A liberdade religiosa nas constituições brasileiras. [S.l.: s.n.].

\section{SITES CONSULTADOS}

COLÉGIO MACKENZIE. Disponível em: <www.mackenzie.br10283.html>. Acesso em: 21 out. 2008.

HISTEDBR - Grupo de Estudos e Pesquisas "História, Sociedade e Educação no Brasil".

Glossário. Disponível em:

<http://www.histedbr.fae.unicamp.br/navegando/glossario/verb_c_ultramontanismo.htm >. Acesso em: 05 ago. 2008.

MONTFORT ASSOCIAÇÃO CULTURAL Disponível em:

$<$ www.montfort.org.br/index.php? seçao $=$ documentos \&subseçao $=$ concilios \& artigo $=$ trento \&lang=bra $>$. Acesso em: 25 ago. 2008

VERITATIS. Disponível em: <www.veritatis.com.br>. Acesso em 21 out.2008

O espaçamento entre as linhas das referências é esse mesmo? 


\section{NOTAS}

${ }^{1}$ Esse tema foi aprofundado na dissertação de mestrado e na tese de doutorado de OLIVEIRA, Lúcia Helena M.de M.

2 AZZI, 1991.

${ }^{3}$ Padroado significa direito de protetor, por quem fundou ou dotou uma igreja. Direito de conferir benefícios eclesiásticos. No Brasil, segundo os textos historiográficos, o termo Padroado se refere ao direito de autoridade da Coroa portuguesa a Igreja católica, nos territórios de domínio Lusitano. Esse direito do Padroado consistiu na delegação de poderes ao rei de Portugal, concedida pelos papas, em forma de diversas bulas papais, uma das quais uniu perpetuamente a Coroa Portuguesa à Ordem de Cristo, em 30 de dezembro de 1551. Desde então, no Reino Português, o Rei passou a ser também o patrono e protetor da Igreja, com as seguintes obrigações e deveres: a) zelar pelas Leis da Igreja; b) enviar missionários evangelizadores para as terras descobertas; c)sustentar a Igreja nestas terras. O Rei tinha também direitos do padroado, como por exemplo, arrecadar dízimos, apresentar os candidatos aos postos eclesiásticos, sobretudo bispos, o que dava poder político muito grande, pois, nesse caso, os bispos ficavam submetidos a ele (HISTEDBR, 2008).

${ }^{4}$ No século XIV aproximadamente, o Tratado de João Quidort (João de Paris), frade dominicano e crítico da Igreja, discutiu profundamente sobre o poder régio e o papal. Afirma ele que o homem político, civil e a autoridade civil não se opõem, nem negam a autoridade religiosa; separa nitidamente as esferas civil e religiosa e afirma que, compete ao poder civil ocupar-se com a vida terrena dos homens e ao poder religioso voltar-se para administração dos sacramentos (p. 28). Em suas argumentações Quidort migra a ideia de que o Papa é fonte de todo poder humano, para colocar esse poder em Deus, de onde derivam igualmente o papado e a realeza. Obra de importante relevância para a definição de que modo o rei interferiria ou não nas questões da Igreja (QUIDORT, 1989).

${ }^{5}$ Galicanismo (Gália/antiga França) surge do descontentamento das ingerências da Cúria Romana em relação ao clero francês. O mesmo proclama a Declaratio cleri gallicani de potestate ecclesistica e estabelece que os reis e os príncipes não estavam sujeitos nas coisas temporais a qualquer poder eclesiástico, nem podiam ser depostos pela Igreja em nome do chamado poder das chaves. Por outro lado, a autoridade do papa deveria sujeitar-se às determinações dos concílios (VERITATIS SPLENDOR, 2008).

6 Antonio Pereira de Figueiredo estudou com os jesuítas, mas, tornou-se oratoriano (Lisboa). Teólogo, canonista e erudito, defensor do regalismo (AZZI, 1991).

${ }^{7}$ O Concílio de Trento também denominado XIX Concílio Ecumênico Contra os invasores do século XVI, reuniu-se de 1545-1563 (18 anos) para elaborar um documento cujo teor seria o combate às inovações doutrinárias protestantes e, nesse sentido, reforçou alguns tópicos muito importantes da doutrina católica, como a fé católica, os livros sagrados, o pecado riginal, a justificação do homem, os sacramentos, a Eucaristia, a penitência, a missa, a ordem, o matrimônio, o purgatório, a Trindade, a encarnação e a profissão de fé. Foi convocado pelo papa III. Esse estudo também foi denominado de Contra-Reforma. Os decretos tridentinos e os diplomas emanados do Concílio, foram os principais documentos que orientaram o direito eclesiástico, até a promulgação do Código do Direito Canônico em 1917 (MONTFORT ASSOCIAÇÃO CULTURAL, 2008).

${ }^{8}$ As encíclicas publicadas foram Aquele Deus (1831), As armas valorosas (1831), Cum Primus as Aures (1832), Mirari Vos 1832) Singulari Nos (1834), In Supremo (1839), Probe Nostes (1840) e Inter Praecipuas (1844) (IGREJA CATÓLICA, 1999).

${ }^{9}$ Passa a ser, em 1885, Instituto de São Paulo.

${ }^{10}$ Transferido em 1893 para Lavras/MG, como Instituto Gammon.

${ }^{11}$ Mackenzi College, 1894.

12 Atualmente Colégio Agnes Erskine.

${ }^{13}$ Anexo ao Seminário Norte.

${ }^{14}$ Os protestantes ocuparam Campinas/SP, fundaram o International (já está no quadro anterior), Colégio São João, Colégio Piracicabano em Piracicaba, Colégio Pestana e Escola Neutralidade (ligados A Hangel Pestana), Colégio Morton e Colégio Mamede (HILSDORF, 1986).

${ }^{15}$ Ver HILSDORF, 1986. Um grande representante da vertente protestante no Brasil foi Rangel Pestana, cujo projeto foi amplamente discutido na obra citada Francisco Rangel Pestana, jornalista, político, educador.

16 A carta encíclica Rerum Novarum foi escrita por Leão XIII e publicada em 15/05/1891 (IGREJA CATÓLICA, 2005).

${ }^{17}$ A carta encíclica Immortale Dei foi publicada em 01 de novembro de 1885 pelo Papa Leão XIII (IGREJA CATÒLICA, 2005).

${ }^{18}$ A carta encíclica Libertas foi publicada em 20 de junho de 1888 pelo Papa Leão XIII (Ibidem). 
${ }^{19}$ O Sillabus foi elaborado por uma comissão de cardeais com base em uma carta pastoral do bispo Olimpo Gerbert de Perpignan (1860), cujas 85 proposições elaboradas por ele retornam no Syllabus. Nesse documento há a condenação do panteísmo, naturalismo, racionalismo absoluto, racionalismo moderado, indiferentismo, latifundinarismo, socialismo, comunismo, sociedades secretas, sociedades bíblicas, sociedades clérico-liberais, os erros da sociedade civil considerada em si mesmo e nas suas relações com a Igreja, erros a respeito da ética natural e cristã, erros a respeito do matrimônio cristão, erros relativos à soberania temporal do romano Pontífice, erros que se referem ao liberalismo moderno (IGREJA CATÒLICA, 1999).

${ }^{19}$ A carta encíclica Quanta Cura foi escrita por Pio IX e publicada em 08 de dezembro de 1864 (IGREJA CATÓLICA, 1999).

${ }^{20}$ A carta encíclica Quanta Cura foi escrita por Pio IX e publicada em 08 de dezembro de 1864 (IGREJA CATÒLICA, 1999).

${ }^{21}$ A encíclica Exorte in ista foi escrita em 29 de abril de1876 (IGREJA CATÒLICA, 1999).

22 A encíclica Fin Dalla Prima foi escrita por Pio X e publicada em 18 de outubro de 1903 (IGREJA CATÒLICA, 2002).

${ }^{23}$ A carta encíclica foi escrita por Leão XIII e publicada em 28 de dezembro de 1878 (IGREJA CATÓLICA, 2005).

${ }^{24}$ A carta Encíclica Aeterni Patris foi escrita por Leão XII e publicada em 04 de agosto de 1879 (IGREJA CATÓLICA, 2005).

${ }^{25}$ Essa pastoral foi discutida e publicada em função do $4^{\circ}$ ano do centenário do descobrimento do Brasil. A carta pastoral de 1900 contou com a participação dos arcebispos da Bahia e Rio de Janeiro. Também com os bispos de Diamantina, Cuiabá, São Paulo, São Pedro do Rio Grande do Sul, Fortaleza, Olinda, Mariana, Goiás, Petrópolis, Paraíba, Amazonas, Curitiba, Pará, Espírito Santo e o Monsenhor João Tolentino Guedelha Mourão, vigário capelar de São Luís do Maranhão.

Artigo recebido em: 10/09/2010

Aprovado em: 12/12/2010 